\title{
Systematic Review and Meta-Analyses Assessment of the Clinical Efficacy of Bismuth Subsalicylate for Prevention and Treatment of Infectious Diarrhea
}

\author{
Jose M. Brum ${ }^{1} \cdot$ Roger D. Gibb ${ }^{1}$ - David L. Ramsey ${ }^{1}$. Guhan Balan ${ }^{1}$ - Bruce R. Yacyshyn ${ }^{2}$ (D)
}

Received: 10 March 2020 / Accepted: 21 July 2020 / Published online: 8 August 2020

(c) The Author(s) 2020

\begin{abstract}
Background A large number of studies have evaluated the pharmacology, safety, and/or efficacy of bismuth subsalicylate for the relief of common gastrointestinal symptoms, diarrhea and vomiting due to acute gastroenteritis. In addition, short-term $(48 \mathrm{~h})$ medication with bismuth subsalicylate is known to be effective against infectious gastroenteritis such as travelers' diarrhea.

Aims Previous studies have documented the bacteriostatic/bactericidal effects of bismuth subsalicylate against a variety of pathogenic gastrointestinal bacteria. However, meta-analyses of the clinical efficacy of bismuth subsalicylate for both prevention and treatment of travelers' diarrhea have not yet been published.

Methods A total of 14 clinical studies (from 1970s to 2007) comprised the core data used in this assessment of efficacy of bismuth subsalicylate against infectious (including travelers') diarrhea. These studies allowed for statistical meta-analyses regarding prevention (three travelers' diarrhea studies) and treatment of infectious diarrhea (11 studies [five travelers' diarrhea]).

Results The results show that subjects treated with bismuth subsalicylate for up to 21 days have 3.5 times greater odds of preventing travelers' diarrhea compared with placebo (95\% CI 2.1, 5.9; $p<0.001)$. In addition, subjects with infectious diarrhea treated with bismuth subsalicylate had 3.7 times greater odds of diarrhea relief (recorded on diaries as subjective symptomatic improvement) compared to those receiving placebo (95\% CI 2.1, 6.3; $p<0.001$ ).

Conclusions This systematic review and meta-analysis suggests that bismuth subsalicylate can be beneficial for those at risk or affected by food and waterborne diarrheal disease such as traveler's (infectious) diarrhea, and may decrease the risk of inappropriate antibiotic utilization.
\end{abstract}

Keywords Bismuth compounds · Infectious diarrhea $\cdot$ Traveler's diarrhea $\cdot$ Infectious gastroenteritis $\cdot$ Viral gastroenteritis

\section{Introduction}

Gastrointestinal (GI) symptoms triggered by foodborne diseases are often of infectious nature. Although these conditions are usually benign and self-limiting, diarrheal

Bruce R. Yacyshyn

Bruce.Yacyshyn@Louisville.edu

1 Procter and Gamble Global Clinical Sciences, Health Care and Quantitative Sciences, 8700 Mason Montgomery Road, Mason, OH 45040, USA

2 Division of Gastroenterology, Hepatology and Nutrition, University of Louisville School of Medicine, Louisville, KY 40292, USA episodes can infrequently cause severe fluid and electrolyte loss acutely resulting in severe dehydration [1].

Acute gastroenteritis (AGE) causing diarrhea and vomiting is a major cause of illness in the USA; an estimated 179 million episodes occur annually [2]. Although AGE is caused by a variety of infectious and noninfectious causes, Noroviruses are the leading cause of epidemic gastroenteritis, detected in approximately $50 \%$ of all AGE outbreaks across Europe and the USA [3, 4].

In the USA and elsewhere, infectious diarrhea caused by traveling is a major burden and although rarely fatal, foodborne and waterborne diarrheal illnesses are extremely common. Nevertheless, even in the USA, up to 1 in 6 , or 48 million Americans are affected yearly, resulting in 128,000 hospitalizations and nearly 3000 deaths, per CDC data [5]. 
Also, rotavirus has been the leading cause of global mortality due to diarrhea in all ages $(15 \cdot 2 \%)$, closely followed by Shigella (12.5\%) and Salmonella infections (6.9\%) [6].

Hall et al. [7] analyzed data reported through the national outbreak reporting system, NORS, during 2009 and 2010. Of 4455 outbreaks reported during this time period, $98 \%$ were AGE outbreaks associated with approximately 3000 hospitalizations and 168 deaths [7]. The authors reported that a single etiology was implicated in $64 \%$ of the outbreaks. Among the single etiologies, Norovirus was the leading cause of the outbreaks (68\%) and responsible for $86 \%$ of the deaths observed in the study. Salmonella spp. (13\%), Shigella spp. (4\%), and Shiga toxin-producing Escherichia coli (STEC, 4\%) were the next most frequent etiologies responsible for outbreaks, respectively. Salmonella spp. was associated with more than 700 hospitalizations (32\%) and was the second most frequent cause of death [7].

According to the CDC, travelers' diarrhea (TD), a subset of AGE including incidents occurring on cruise ships, is the most predictable travel-related illness in all travelers [8]. Bacterial pathogens account for $80-90 \%$ of TD, and intestinal viruses usually account for 5-8\% of illnesses. Overall, the most common pathogen is enterotoxigenic Escherichia coli, followed by Campylobacter jejuni, Shigella spp., and Salmonella spp. Although most cases of TD are acute and self-limited, a certain percentage of travelers will develop persistent ( $>14$ days) gastrointestinal symptoms [9].

Readily available over-the-counter (OTC) medication for symptomatic relief and appropriate oral hydration can be health-saving measures of great convenience for those affected by TD. Bismuth subsalicylate (BSS) is a non-proprietary monograph product that is available in the USA and abroad, over-the-counter (OTC). Of all OTC medications for TD, BSS has the greatest antimicrobial activity [10] against pathogenic bacteria [11-13]. A study done by Gump et al. [14] first demonstrated the ability of BSS to decrease the invasiveness of enteropathic bacteria in gastrointestinal epithelial cells. Electron-dense deposits of bismuth were found in Yersinia enterocolitica cells exposed to BSS, indicating that the antibacterial effect of BSS was mediated by its ability to increase permeability of the bacterial cell wall and increase bismuth concentrations in bacterial cells $[14,15]$. Other studies had indicated that the exposure of bacteria to BSS resulted in a loss of membrane integrity and, possibly, inactivation of cellular ATP synthesis leading to death of the organism [16]. More recently, Pitz et al. [13] verified in vitro the antimicrobial effects of BSS and bismuth oxychloride (BiOCl) on key pathogens, such as Escherichia coli O104:H21 (surrogate to 2011 German outbreak strain), Salmonella, and Norovirus (NoV). These authors showed that bismuth reduced bacterial growth significantly resulting in less than $10 \mathrm{cfu} / \mathrm{ml}$ within $24 \mathrm{~h}$. C. difficile was the most susceptible pathogen to the bismuth challenges in the antibacterial assays. BSS also exhibited significant inhibition on viral invasion of host cells and viral efficacy. Both $\mathrm{BSS}$ and bismuth oxychloride (BiOCl, which is formed in the stomach after ingestion of BSS) at low concentration $(0.004-0.13 \mathrm{mg} / \mathrm{mL})$ significantly reduced NoV RNA levels, suggesting an in vivo antiviral mechanism. BSS has been shown to also have antiviral activity since it inhibited replication of four strains of rotavirus in tissue culture cells and caused a dose-dependent reduction in the growth of a number of enteric viruses [17, 18].

Historically, BSS has been indicated and effectively used for treatment of TD or enteric infection mainly when vomiting occurs [19-25]. Although the safety and efficacy of BSS are well known [26, 27], some of the research done with BSS resides within the industry and has not been published. The data collected in such studies matched the regulatory requirements of the time of the study and determined a body of evidence for the regulatory approval of BSS.

Given the importance of easy access to non-antibiotic therapy for prevention and treatment of diarrheal disease, this review includes previously unpublished clinical studies regarding BSS safety and efficacy. Meta-analyses of randomized controlled clinical trials were performed with studies specifically designed to capture prevention of manifestation and relief of diarrhea.

\section{Methods}

A systematic review of the medical literature was performed to identify randomized, placebo-controlled clinical studies that evaluated the efficacy of BSS for the prevention and treatment of diarrhea. Results were reported in accordance with the Preferred Reporting Items for Systematic Reviews and Meta-Analyses (PRISMA) guidelines. The review included searches with Medline (1950-2018), Embase (1980-2018), the Cochrane Central Register of Controlled Trials, and Procter and Gamble's clinical study archive. Eligible studies were identified with search terms "bismuth," "subsalicylate," "travelers' diarrhea," "infectious diarrhea," "treatment," "therapy," and "prevention" with no language restrictions imposed. The magnitude of any BSS effect was not used as a study inclusion criterion. Abstracts, articles, and final reports were evaluated independently by each of the five authors. Relevant information needed for metaanalyses, including sample sizes and incidence of diarrhea by treatment group, and was extracted to a database by two independent reviewers and compared for accuracy and completeness. A total of 1869 records were identified through database searching of the terms. Clinical trials and review articles available made 126 publications and 70 Procter and Gamble internal clinical studies with BSS, comprising 196 records for assessment of eligibility. Complete, unrestricted, 
and open access to all Procter and Gamble studies was given to BY during this review process. Only 14 studies (3 prevention, 11 treatment) were eligible for efficacy analyses, and 182 were excluded by diverse reasons listed in Fig. 1. A total of 24 placebo-controlled studies were eligible for integrated safety assessment with a total of 1164 subjects receiving BSS and 1166 receiving placebo.

A total of three meta-analyses were performed to assess specifically the efficacy of BSS for (1) prevention of TD, (2) treatment of infectious diarrhea in general, and (3) treatment of TD. The endpoint in each meta-analysis was binary: success or failure in the prevention or treatment of diarrhea. Data in each meta-analysis were pooled using the generic inverse variance method with random effects model and expressed as an odds ratio with $95 \%$ confidence interval using the Comprehensive Meta-Analysis software version 2.2.064. Heterogeneity was assessed using the Cochran Q-statistic and quantified with the $I^{2}$ statistic. Per protocol efficacy results from each study, i.e., results for subjects compliant with the study protocol, were included in each meta-analysis.

\section{Risk of Bias Assessment}

Risk of bias within individual studies was assessed with respect to selection bias (randomization and allocation concealment), detection bias (blinding of outcomes), attrition bias (incomplete outcomes), and reporting bias (selective reporting). All studies included in the meta-analysis were randomized and blinded, and, therefore, the risk of selection and detection bias was deemed to be low. The risk of reporting bias was also considered to be low, given that all published data and unpublished $\mathrm{P} \& \mathrm{G}$ data were included. Intent-to-treat data were not available for all the studies, and, therefore, the potential for attrition bias exists.

\section{Results}

\section{Prevention of Travelers' Diarrhea Meta-Analysis}

The first meta-analysis specifically assessed the diarrhea preventive effects of BSS in generally healthy adults who had no diarrhea at the time of randomization. Five P\&Gsponsored studies were identified for consideration. Out of the five studies, three were designed for prevention of TD, and two involved induced diarrhea through viral inoculation (Norwalk agent or Norovirus) or chemical irritation (castor oil consumption)-induced diarrhea. Although BSS had shown efficacy in these two chemical irritation studies, in order to maintain relevance to populations at risk for TD, only the three naturally occurring diarrhea studies were considered for meta-analysis. All three studies $(n=404$ subjects, age between 16 and 70 years) followed a similar parallel group, placebo-controlled design in diarrhea-free individuals embarking on a trip to tropical countries (Mexico and African destinations) known for elevated incidence of TD. All subjects initiated a 21-day prophylactic BSS dosing regimen
Fig. 1 Flow diagram for metaanalysis

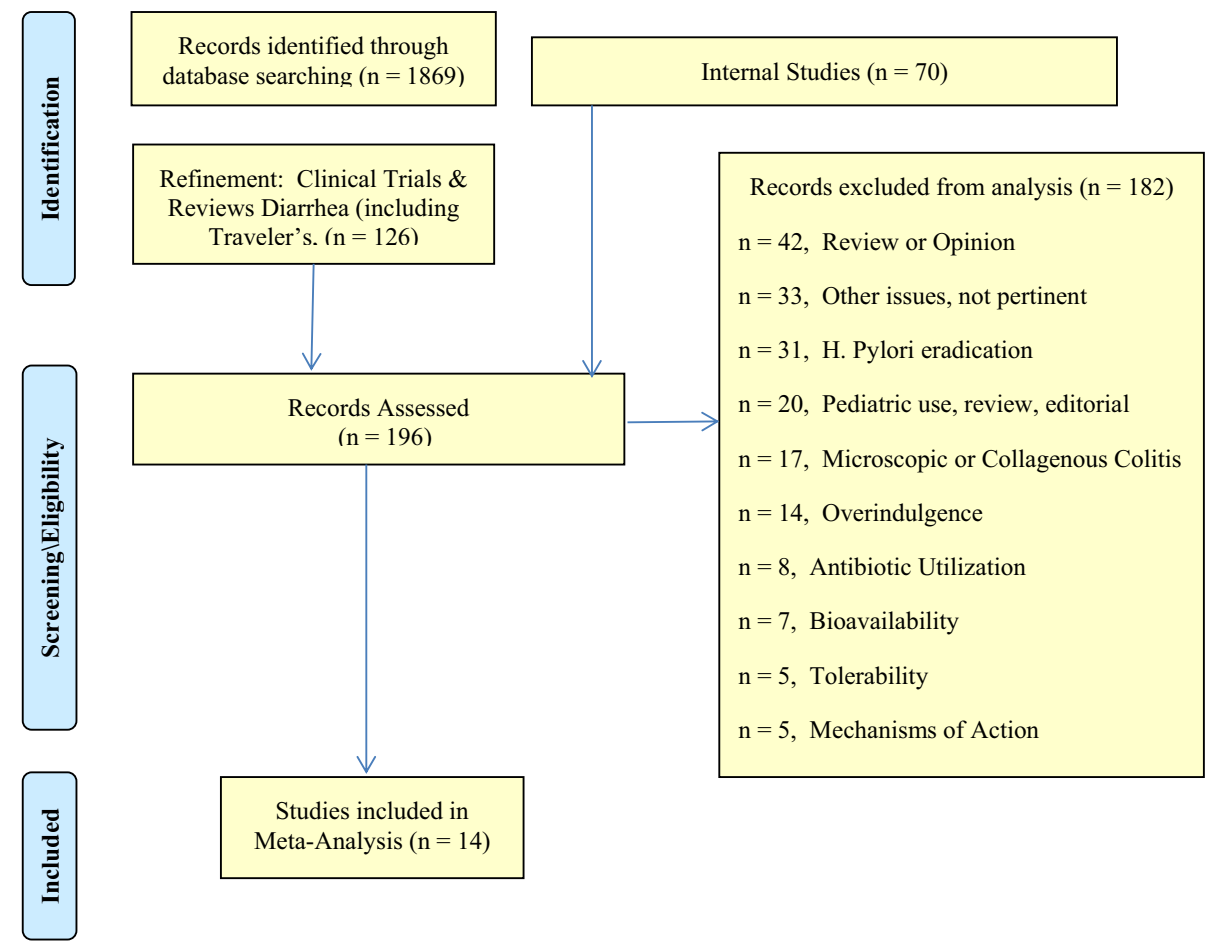


(one study used BSS tablets QID to a total of $2.1 \mathrm{~g} / \mathrm{day}$, the second study used oral suspension of $1050 \mathrm{mg}$ QID to a total dose of $4.2 \mathrm{~g} / \mathrm{day}$, and the third study used tablets BID to total dose of $2.1 \mathrm{~g} /$ day) starting from 1 day before departure or 2 days after arrival at the trip destination. Study details, including the highest dose administered, the criteria for diarrhea diagnosis, and findings, are summarized in Table 1.

The meta-analysis efficacy endpoint was self-assessed diarrhea (presence/absence) during the 21-day treatment period. Meta-analysis results are reported in Fig. 2 in terms of odds ratios and $95 \%$ confidence intervals with larger values indicative of greater efficacy for BSS relative to placebo. The data indicate that subjects who dosed BSS had 3.5 times greater odds of not developing TD than subjects who dosed placebo (95\% CI 2.1, 5.9; $p<0.001, I^{2}=27 \%$ ).

\section{Treatment of All Infectious Diarrhea Meta-Analysis}

The second meta-analysis focused on the effect of intervention in otherwise generally healthy adults with acute diarrhea (probably infectious) at the time of randomization. A total of 14 clinical studies were identified for consideration. Johnson et al. [28] and two unpublished P\&G studies did not have negative controls and, therefore, were excluded. The remaining 11 studies ( $n=840$ subjects) consisted of one published $P \& G$ study and ten unpublished $P \& G$ studies, all of which compared BSS to negative control over a 1- to 2-day treatment period. Nine of the studies dosed $4.2 \mathrm{~g} /$ day BSS (1400 mg tid), and two studies dosed $2.1 \mathrm{~g} /$ day (700 mg tid) BSS. Study details including findings are summarized in Table 2.

The endpoint of interest in this meta-analysis was relief of diarrhea, assessed by either the patient or a physician. The odds ratio and 95\% confidence interval for each study are reported in Fig. 3, together with the overall summary effect. The results indicate that subjects who dosed BSS had 3.7 times greater odds of experiencing relief of infectious diarrhea than subjects who dosed negative control (95\% CI 2.1, 6.3; $\left.p<0.001, I^{2}=42 \%\right)$.

\section{Treatment of Travelers' Diarrhea Meta-Analysis}

The third meta-analysis focused specifically on traveler's diarrhea, a subset $(n=5)$ of the 11 studies (DuPont et al. 1977 [29]; Study 3; Study 5; Study 6; and Study 8) included in the earlier meta-analysis to assess treatment of all infectious diarrhea. These five studies were selected to determine the efficacy of BSS for the treatment of TD only. The results (Fig. 4) indicate that subjects who dosed BSS had 3.1 times greater odds of experiencing relief of TD than subjects who dosed negative control (95\% CI 1.9, 5.0; $p<0.001, I^{2}=0 \%$ ).

Since the inter-study heterogeneity statistics $I^{2}$ did not exceed $42 \%$ across the three meta-analyses, none of the meta-analyses were considered to have substantial heterogeneity.

\section{Adverse Events}

The most common adverse events (at least $2 \%$ in either placebo or BSS group) experienced by participants in safety studies in adults (24 studies, including the 14 studies used for efficacy meta-analyses) were benign and are described in Table 3. Subjects receiving BSS were significantly more likely to experience a transient discoloration of the feces or tongue; this is caused by a well-established reaction of gastrointestinal hydrogen sulfide with bismuth resulting in bismuth sulfide [27, 30].

\section{Discussion}

The global prevalence and consequences of acute infectious diarrhea are increasing [7, 9, 31]. This problem has been compounded by the development of antibiotic-resistant bacteria (MRSA, VRE, and ESBLs) and virulent strains (B1/ NAP1 CDI) [32-34]. Strategies that manage to decrease antibiotic use in hospital patients have been largely successful in reducing resistant bacterial infections from further spread. Concern that resistant bacterial infections will establish themselves in the community is based on facts and ways of mitigating this risk need to be addressed. Use of antibiotic husbandry in the inpatient clinical situation has been shown to be effective for reducing the incidence of Clostridium difficile infections in at least one institution (UPMC) [35]. Clearly, a non-antibiotic treatment strategy in appropriate outpatients remains a priority. Here, we have shown for the first-time industry and academic data that support the use of a readily available antimicrobial medication for the treatment of infectious diarrhea and prevention of TD. Dupont and Steffen in 2016 warned about the ongoing use of antimicrobial agents for the treatment and prevention of travelers' diarrhea with ESBLs and the need for consensus recommendations [34]. This clearly has been an ongoing and common problem that has yet to be addressed, and the expansion of "newer" agents of MDR with bacteria such as E. coli ST 131 as the latest agent is case in point of the concept of bacterial ecology and expansion. Such increasing worldwide occurrences need to be studied in the context of associated antibiotics used for treatment, locations of acquisition, and the development of personalized treatment methods to manage the expansion of these epidemics, including the consideration of non-antibiotic strategies for prevention and treatment $[36,37]$.

In our work, our meta-analyses results have shown that individuals using BSS have 3.5 times greater odds for prevention of TD $(p<0.001)$, and, once diarrhea is manifested, 


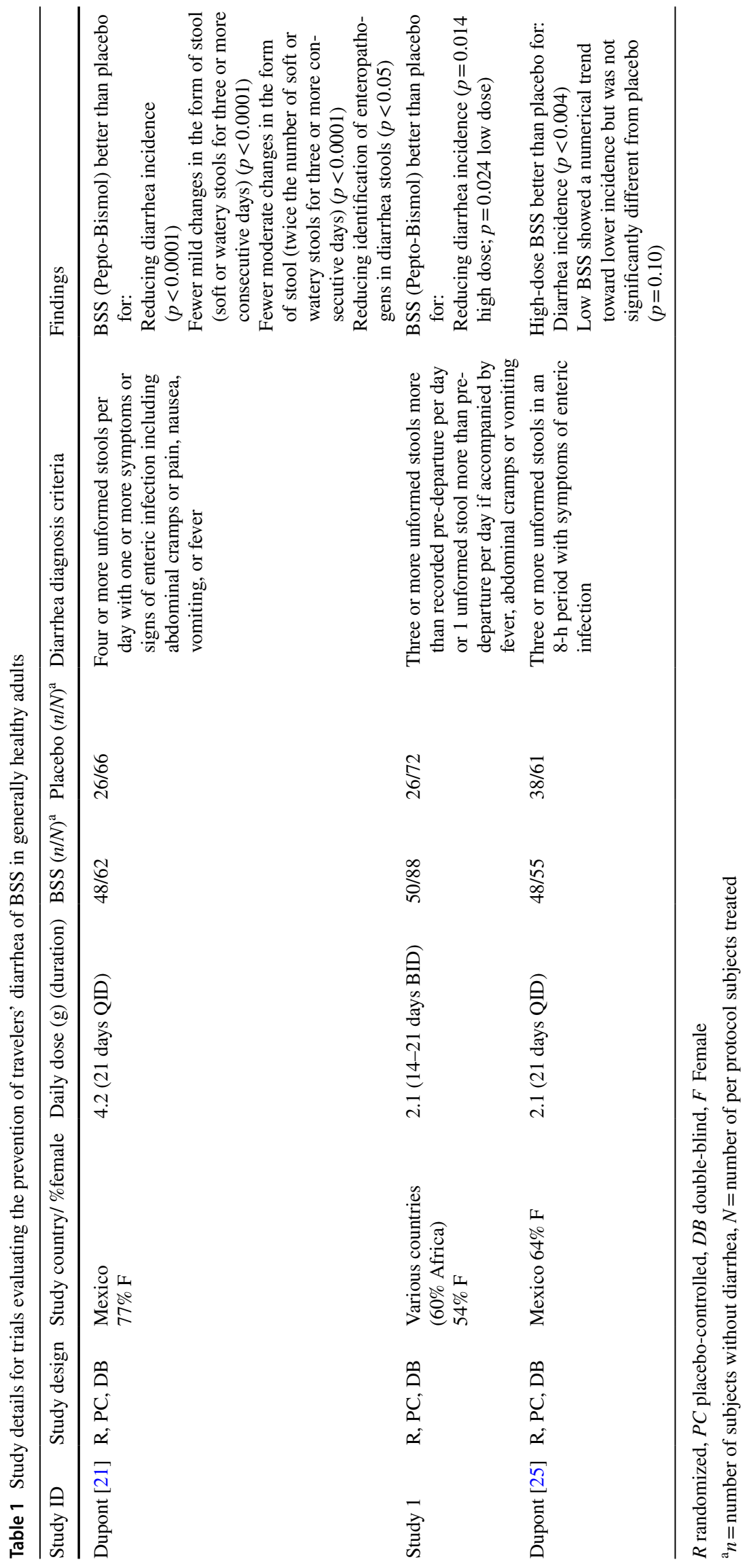


Fig. 2 Meta-analysis of trials evaluating the prevention of traveler's diarrhea with BSS in generally healthy adults. Heterogeneity: $I^{2}=27 \%, p=0.252$

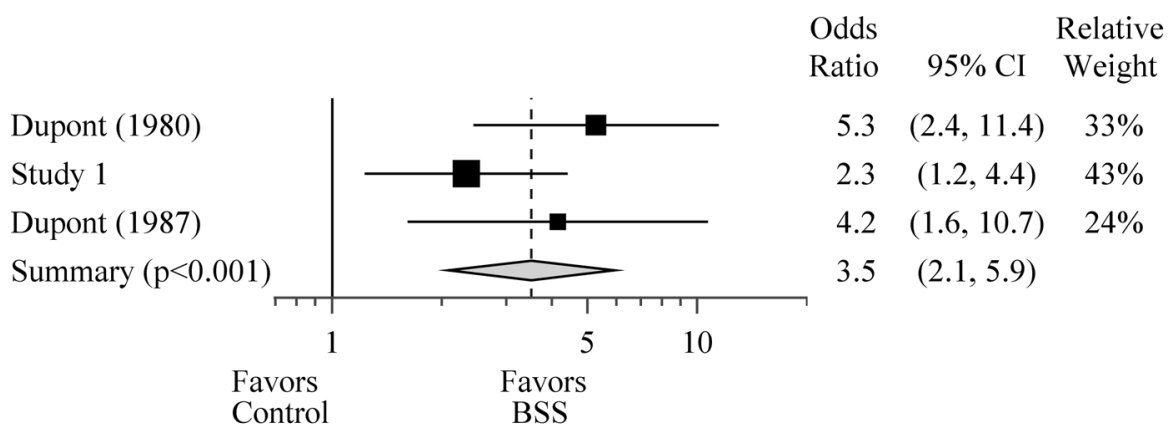

the odds of relief are 3.7 times greater with BSS compared to placebo $(p<0.001)$. Preventive therapy for those at high risk, and therapeutic approach for subjects with active symptoms, using a convenient OTC medication could have a significant impact on complications associated with infectious diarrhea [32].

BSS exerts its antidiarrheal effects through several different mechanisms that affect the symptoms (anti-secretory), and the cause (microbial) of diarrhea. BSS treats the symptom by inhibiting secretion of fluids while stimulating absorption to help normalize fluid movement [27]. In addition to normalizing fluid movement, BSS decreases the gastrointestinal motility to help relieve the symptoms [28].

In regard to antimicrobial activity, BSS has been shown to be effective at inhibiting growth of common causative organisms of diarrhea, such as E. coli, Salmonella sp., Shigella sp., and Vibrio sp., both in vitro and in vivo [10]. BSS also binds and inactivates bacterial toxins and bile acids [12, 14] that can cause diarrhea. Bismuth compounds even at subbacteriostatic and sub-bactericidal concentrations decrease pathogenic bacterial invasion of gut epithelial cells.

The antimicrobial effect of BSS in humans was demonstrated in a study conducted in volunteers who were given either BSS or placebo 8 and $2 \mathrm{~h}$ prior to and for 3 days after receiving a dose of enterotoxigenic $E$. coli [38]. Enterotoxigenic $E$. coli was recovered from 2 of 14 patients who received BSS and from 13 of 15 patients who received placebo. Furthermore, antibacterial effect of BSS was detected in a placebo-controlled study conducted in 30 infants with diarrhea [39]. Clearance of enterotoxigenic E. coli was observed in all BSS-treated patients $(15 / 15)$ but not in placebo-treated patients $(9 / 15)$.

The isolation of bacterial pathogens from the stools of patients with infectious diarrhea is reduced in patients treated with BSS compared to placebo-treated controls. In the study done by Dupont et al. (1977) [29] in Mexico for the treatment of traveler's diarrhea with BSS, pathogens were isolated from the feces of 4 of 12 patients receiving BSS compared to 27 of 38 in placebo. In a study done by Graham et a1 (1983) [38], in a metabolic unit with monitored healthy $(n=14)$ volunteers given BSS prophylactically before administration of ETEC orally, recovery of toxigenic $E$ coli from stools was seen in 2 of 14 patients given BSS compared to recovery from 13 of 15 stools in the placebotreated group. Similarly, in the prophylaxis study by Steffen et al. [40] among travelers to Africa, pathogens could not be isolated in the stools of any of the six patients given BSS, but positive cultures were found in 6 of 12 subjects receiving placebo.

These studies support the clinical antimicrobial activity of BSS. Although BSS inhibits bacterial pathogens in vitro at the concentrations similar to what is achieved by recommended oral doses, this antimicrobial activity is not sufficient to significantly change the microbial composition of the normal microbiota detected in feces. While the overall concentrations and types of colonic bacteria are potentially unchanged by oral ingestion of OTC doses of BSS, there are some indications that fermentation of lactose and raffinose is reduced by colonic bacteria in patients treated with BSS $[18,41]$.

State-of-the-art quantitative PCR assays for pathogens causing TD have shown more recently that enteropathogen E. coli (47\%), enteroaggregative E. coli (46\%), enterotoxigenic E. coli (22\%), enterohemorrhagic E. coli (7\%), campylobacter (6\%), Shigella (2\%), or enteroinvasive E. coli $(2 \%)$, and salmonella (2\%) were detectable from stools of subjects with TD [42-44].

Recently, research was conducted using a time-kill assay with pure cultures of six pathogens of the gastrointestinal microflora including E. coli 0157:H7. Transmission electron microscopy was used to learn how BSS interacts with bacteria at the cellular level. Within a $0.5 \mathrm{~h}$ of BSS exposure, bismuth was detected on the bacterial cell membrane and inside the cells. Results from the study illustrate that pure BSS salt, Pepto-Bismol, and the hydrolyzed forms (bismuth hydroxide and bismuth carbonate) either inhibited bacterial growth or eradicated the bacteria for all species tested within a 24-h period [13].

BSS when given prophylactically in much lower daily doses than required for treatment can significantly decrease the incidence of TD. The fact that the bismuth component of BSS is an agent that is very poorly absorbed favors a 
Table 2 Study details for trials evaluating intervention in generally healthy adults with diarrhea

\begin{tabular}{|c|c|c|c|c|c|c|c|}
\hline Study ID & Study design & $\begin{array}{l}\text { Study country/\% } \\
\text { female }\end{array}$ & Daily dose $(\mathrm{g})$ interval & $\operatorname{BSS}(n / N)^{\mathrm{a}}$ & Control $(n / N)^{\mathrm{a}}$ & $\begin{array}{l}\text { Treatment } \\
\text { period } \\
\text { (days) }\end{array}$ & Findings \\
\hline $\begin{array}{c}\text { Dupont } \\
{[29]^{b}}\end{array}$ & $\mathrm{R}, \mathrm{PC}, \mathrm{DB}$ & Mexico & $\begin{array}{l}4.2 \\
30 \mathrm{ml} \text { every } 1 / 2 \mathrm{HR} \text { up } \\
\text { to eight doses }\end{array}$ & $37 / 46$ & $26 / 41$ & 1 & $\begin{array}{l}\text { BSS (Pepto-Bismol) } \\
\text { (both doses) better } \\
\text { than placebo for: } \\
\text { Number of unformed } \\
\text { stools for } 4-24 \mathrm{~h} \text { after } \\
\text { therapy }\end{array}$ \\
\hline Study 2 & $\mathrm{R}, \mathrm{PC}, \mathrm{DB}$ & Mexico & $\begin{array}{l}4.2 \\
30 \mathrm{ml} \text { every } \\
30-60 \text { min up to } \\
\text { eight doses }\end{array}$ & $26 / 29$ & $8 / 32$ & 1 & $\begin{array}{l}\text { BSS (Pepto-Bismol) } \\
\text { better than placebo } \\
\text { for: } \\
\text { Physician's overall } \\
\text { subjective feel- } \\
\text { ing of relief within } \\
4 \mathrm{~h}(p<0.01) \text { (also } \\
\text { Lomotil was effective) } \\
\text { Patient's subjective } \\
\text { relief in } 4 \text { h showed } \\
\text { Pepto-Bismol 79\%; } \\
\text { PB better than Pl } \\
p<0.01 \\
\text { Lomotil } 64 \% \text { : Lomotil } \\
\text { better than Pl } p<0.01 \\
\text { Placebo } 25 \%\end{array}$ \\
\hline Study 3 & $\mathrm{R}, \mathrm{PC}, \mathrm{DB}$ & Mexico $61 \% \mathrm{~F}$ & $\begin{array}{l}4.2 \\
30 \mathrm{ml} \text { every } 1 / 2 \mathrm{HR} \text { up } \\
\text { to eight doses }\end{array}$ & $41 / 49$ & $29 / 50$ & 2 & $\begin{array}{l}\text { BSS (Pepto-Bismol) } \\
\text { better than placebo } \\
\text { for: } \\
\text { Time to last unformed } \\
\text { stool }(p<0.05) \\
\text { Time to total relief } \\
(p=0.02) \\
\text { Inv.'s assessment } \\
\text { of time to relief } \\
(p=0.02) \\
\text { Percentage with relief } \\
\text { at } 72 \text { h }(p<0.01) \\
\text { Improvement in stool } \\
\text { consistency }(p<0.01) \\
\text { Patient's global assess- } \\
\text { ment } p=0.03 \text { (day } 1) \\
\text { and } p=0.06 \text { (day } 2) \\
\text { Reduced ave. number } \\
\text { of unformed stools } \\
\text { during first } 24-h \\
\text { period }(p=0.04)\end{array}$ \\
\hline Study 4 & $\mathrm{R}, \mathrm{PC}, \mathrm{DB}$ & $\begin{array}{l}\text { USA } \\
49 \% \mathrm{~F}\end{array}$ & $\begin{array}{l}4.2 \\
30 \mathrm{ml} \text { every } \\
30-60 \text { min until } \\
\text { seven or eight doses }\end{array}$ & $30 / 49$ & $23 / 49$ & 1 & $\begin{array}{l}\text { BSS (Pepto-Bismol) } \\
\text { better than placebo } \\
\text { for: } \\
\text { Successful relief for } \\
\text { both BSS formula- } \\
\text { tions }(p<0.05) \\
\text { (pooled analyses) } \\
\text { No significant dif- } \\
\text { ferences were seen } \\
\text { between BSS formu- } \\
\text { lations }\end{array}$ \\
\hline Study 5 & $\mathrm{R}, \mathrm{PC}, \mathrm{DB}$ & Mexico & $\begin{array}{l}4.2 \\
30 \mathrm{ml} \text { every } \\
30-60 \mathrm{~min} \text { as } \\
\text { needed up to } 8 \mathrm{~h}\end{array}$ & $54 / 57$ & $61 / 69$ & 1 & $\begin{array}{l}\text { No significant treatment } \\
\text { effects were detected. } \\
\text { All treatments pro- } \\
\text { vided similar relief }\end{array}$ \\
\hline
\end{tabular}


Table 2 (continued)

\begin{tabular}{|c|c|c|c|c|c|c|c|}
\hline Study ID & Study design & $\begin{array}{l}\text { Study country/\% } \\
\text { female }\end{array}$ & Daily dose $(\mathrm{g})$ interval & $\operatorname{BSS}(n / N)^{\mathrm{a}}$ & Control $(n / N)^{\mathrm{a}}$ & $\begin{array}{l}\text { Treatment } \\
\text { period } \\
\text { (days) }\end{array}$ & Findings \\
\hline Study 6 & $\mathrm{R}, \mathrm{C}^{\mathrm{c}}, \mathrm{DB}$ & $\begin{array}{l}\text { Mexico } \\
55 \% \mathrm{~F}\end{array}$ & $\begin{array}{l}4.2 \\
30 \text { ml every } \\
30-60 \text { min up to } \\
\text { eight doses }\end{array}$ & $43 / 45$ & $37 / 47$ & 1 & $\begin{array}{l}\text { BSS (Pepto-Bismol) } \\
\text { better than Kaolin/ } \\
\text { Pectin for: } \\
\text { Good/excellent relief } \\
\text { of diarrhea at } 6 \mathrm{~h} \text { and } \\
12 \mathrm{~h}(p<0.05) \text { (both } \\
\text { formulations of BSS) }\end{array}$ \\
\hline Study 7 & $\mathrm{R}, \mathrm{C}^{\mathrm{d}}, \mathrm{SB}$ & $\begin{array}{l}\text { Mexico } \\
66 \% \mathrm{~F}\end{array}$ & $\begin{array}{l}2.1 \\
60 \mathrm{ml} \text { or } 25 \mathrm{~g} \text { taken } \\
\text { every } 12 \mathrm{~h} \text { for four } \\
\text { consecutive doses }\end{array}$ & $15 / 16$ & $15 / 16$ & 2 & $\begin{array}{l}\text { BSS (Pepto-Bismol) } \\
\text { was better than Dia- } \\
\text { mylex for: } \\
\text { Reduction of cramps } \\
\text { from baseline } \\
\text { (60-72-h time point; } \\
p=0.04) \\
\text { The total stool weight, } \\
\text { the weight of water } \\
\text { content, and the } \\
\text { weight of dry stool } \\
\text { (all significantly } \\
\text { more increased in the } \\
\text { Pepto-Bismol group } \\
\text { than in the Diamylex } \\
\text { group at some time } \\
\text { points; } p \leq 0.06 \text { ) } \\
\text { PB was not different } \\
\text { than Diamylex (prege- } \\
\text { latinized corn starch) } \\
\text { with respect to degree } \\
\text { of relief, total number } \\
\text { of stools, consistency } \\
\text { of stools, and relief of } \\
\text { nausea }\end{array}$ \\
\hline Study 8 & $\mathrm{R}, \mathrm{PC}, \mathrm{DB}$ & $\begin{array}{l}\text { Togo } \\
42 \% \mathrm{~F}\end{array}$ & $\begin{array}{l}4.2 \\
30 \mathrm{ml} \text { every hour for } \\
\text { up to four doses } \\
\text { daily for } 48 \mathrm{~h}\end{array}$ & $56 / 63$ & $41 / 56$ & 2 & $\begin{array}{l}\text { BSS (Pepto-Bismol) } \\
\text { better than placebo } \\
\text { for: } \\
\text { Time to last unformed } \\
\text { stool }(p<0.01) \\
\text { Time to total relief } \\
(p \leq 0.02) \\
\text { Improvement in stool } \\
\text { consistency ( } p \leq 0.02) \\
\text { Improvement in fre- } \\
\text { quency of unformed } \\
\text { and watery stools } \\
(36-48 \text { h) }(p<0.01)\end{array}$ \\
\hline Study 9 & $\mathrm{R}, \mathrm{PC}, \mathrm{DB}$ & $\begin{array}{l}\text { USA } \\
37 \% \mathrm{~F}\end{array}$ & $\begin{array}{l}4.2 \\
30 \mathrm{ml} \text { every } \\
30-60 \text { min until } \\
\text { seven or eight doses }\end{array}$ & $15 / 17$ & $4 / 12$ & 1 & $\begin{array}{l}\text { BSS (Pepto-Bismol) } \\
\text { better than placebo } \\
\text { for: } \\
\text { Combined symptoms } \\
\text { (upset stomach and } \\
\text { diarrhea) }(p<0.01) \\
\text { Upset stomach alone } \\
(p \leq 0.05) \\
\text { Diarrhea alone } \\
(p<0.01) \\
\text { No significant dif- } \\
\text { ferences were seen } \\
\text { between PB formula- } \\
\text { tions }\end{array}$ \\
\hline
\end{tabular}


Table 2 (continued)

\begin{tabular}{|c|c|c|c|c|c|c|c|}
\hline Study ID & Study design & $\begin{array}{l}\text { Study country/\% } \\
\text { female }\end{array}$ & Daily dose $(\mathrm{g})$ interval & $\operatorname{BSS}(n / N)^{\mathrm{a}}$ & Control $(n / N)^{\mathrm{a}}$ & $\begin{array}{l}\text { Treatment } \\
\text { period } \\
\text { (days) }\end{array}$ & Findings \\
\hline Study 10 & $\mathrm{R}, \mathrm{C}^{\mathrm{d}}, \mathrm{SB}$ & $\begin{array}{l}\text { Israel } \\
28 \% \mathrm{~F}\end{array}$ & $\begin{array}{l}2.1 \\
60 \mathrm{ml} \text { or } 25 \mathrm{~g} \text { taken } \\
\text { every } 12 \mathrm{~h} \text { for four } \\
\text { consecutive doses }\end{array}$ & $20 / 21$ & $19 / 19$ & 2 & $\begin{array}{l}\text { Diamylex appears to } \\
\text { be equivalent to BSS } \\
\text { (Pepto-Bismol) with } \\
\text { respect to reduc- } \\
\text { ing the subjective } \\
\text { symptoms of cramps, } \\
\text { nausea, tenesmus, and } \\
\text { vomiting. Further, } \\
\text { both the patient's } \\
\text { and on-site physi- } \\
\text { cian's assessment of } \\
\text { "degree of relief" are } \\
\text { comparable for both } \\
\text { products }\end{array}$ \\
\hline Study 11 & $\mathrm{R}, \mathrm{PC}, \mathrm{SB}$ & $\begin{array}{l}\text { Uzbekistan } \\
47 \% \mathrm{~F}\end{array}$ & $\begin{array}{l}4.2 \\
2 \text { caplets after each } \\
\text { unformed bowel } \\
\text { movement not to } \\
\text { exceed eight doses } \\
\text { (16 caplets) in } 24 \mathrm{~h}\end{array}$ & $26 / 26$ & $25 / 31$ & 2 & $\begin{array}{l}\text { BSS (Pepto-Bismol) } \\
\text { better than placebo } \\
\text { for: } \\
\text { Primary efficacy } \\
\text { variable: time to } \\
\text { last unformed stool } \\
\text { ( } p=0.0162) \\
\text { Loperamide bet- } \\
\text { ter than placebo } \\
\text { ( } p=0.0105) \\
\text { Loperamide not differ- } \\
\text { ent from BSS (Pepto- } \\
\text { Bismol, } p=0.6947 \text { ) } \\
\text { Loperamide bet- } \\
\text { ter than Kold Kare/ } \\
\text { Bektit-M/Pepto- } \\
\text { Bismol combination } \\
\text { ( } p=0.0156) \\
\text { Global assess- } \\
\text { ment of relief and } \\
\text { patient's bowel habit } \\
\text { assessment (bowel } \\
\text { habits back to normal) } \\
\text { ( } p=0.0266 \text { ) }\end{array}$ \\
\hline
\end{tabular}

${ }^{\mathrm{a}} n=$ number of subjects with diarrhea relief, $N=$ number of per protocol subjects treated

${ }^{\mathrm{b}}$ The cited publication combines results for two treatment groups (4.2 g/day BSS and $8.4 \mathrm{~g} / \mathrm{day}$ BSS). To permit calculation of an odds ratio, the standard practice of adding 0.5 to each cell count was followed

${ }^{\mathrm{c}}$ Kaolin-pectin was control for this study

${ }^{\mathrm{d}}$ Diamylex was control for this study

$R$ randomized, $P C$ placebo-controlled, $C$ controlled (efficacy believed to be comparable to placebo), $D B$ double-blind, $S B$ single-blind (investigator), $F$ female

localized antimicrobial effect. The meta-analysis of the efficacy showed that subjects receiving BSS immediately after arriving in the foreign country and before having any symptoms or signs of diarrhea had 3.5 times greater odds of not developing TD than subjects taking placebo as preventative therapy. Corresponding to this clinical preventive efficacy are the findings that BSS even at bacteriostatic and sub-bactericidal concentrations was shown to decrease pathogenic bacteria attachment and invasion of gut epithelial cells [16].
Therefore, utilization of BSS may also help to avoid early unnecessary antibiotic therapy for acute and traveler's diarrhea, a common practice in developing countries. A recent study done by the Center for Disease Control (USA) with 440 outpatients with acute diarrhea and randomized to BSS or placebo in Pakistan showed that BSS was able to reduce the use of antibiotic by $45 \%$ independent of the infectious etiology and by $74 \%$ of bacterial gastroenteritis [45]. 
Fig. 3 Meta-analysis for trials for evaluating intervention in generally healthy adults with infectious diarrhea. Heterogeneity: $I^{2}=42 \%, p=0.069$

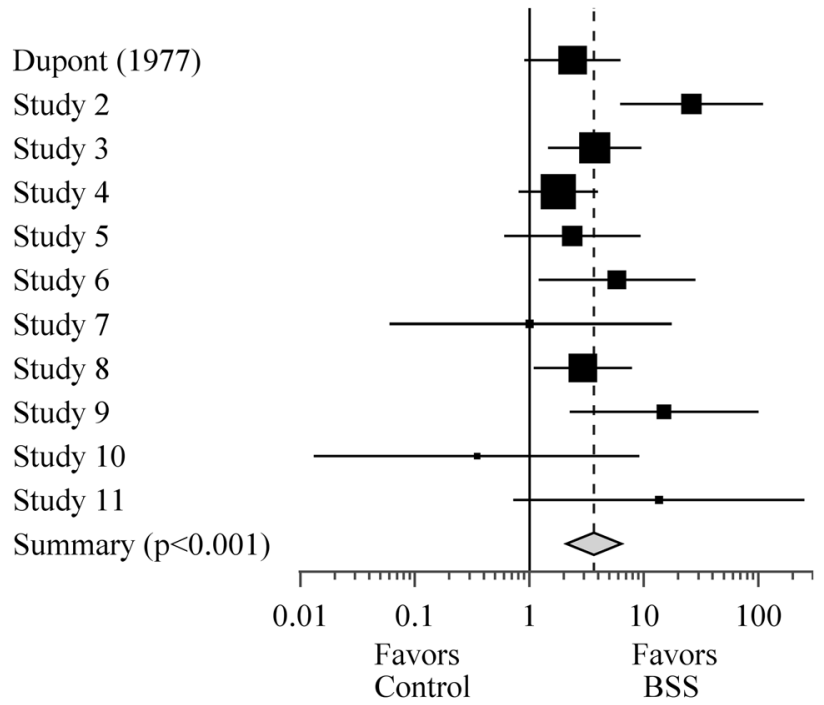

Odds Relative

Ratio 95\% CI Weight

$2.4 \quad(0.9,6.2) \quad 14 \%$

$26.0 \quad(6.2,109.5) \quad 9 \%$

$3.7 \quad(1.5,9.5) \quad 14 \%$

$1.8 \quad(0.8,4.0) \quad 16 \%$

$2.4 \quad(0.6,9.4) \quad 10 \%$

$5.8 \quad(1.2,28.2) \quad 8 \%$

$1.0 \quad(0.1,17.5) \quad 3 \%$

$2.9 \quad(1.1,7.8) \quad 14 \%$

$15.0 \quad(2.2,100.5) \quad 6 \%$

$0.4 \quad(0.0,9.1) \quad 3 \%$

$13.5(0.7,252.3) \quad 3 \%$

$3.7 \quad(2.1,6.3)$
Fig. 4 Meta-analysis for trials for evaluating intervention in generally healthy adults with travelers' diarrhea. Heterogeneity: $I^{2}=0 \%, p=0.877$

Dupont (1977)
Study 3
Study 5
Study 6
Study 8
Summary $(\mathrm{p}<0.001)$

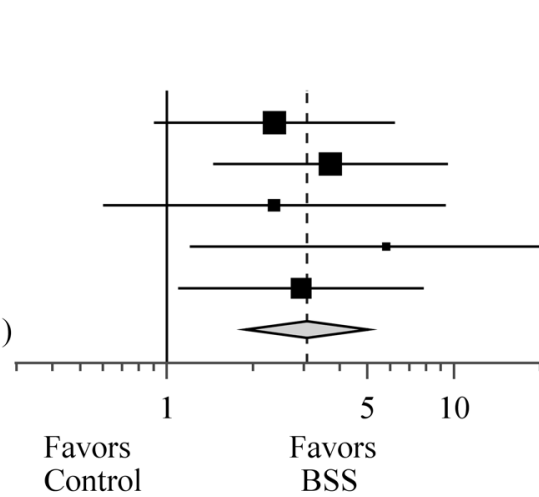

Odds

95\% CI Weight

$2.4 \quad(0.9,6.2) \quad 26 \%$

$3.7 \quad(1.5,9.5) \quad 27 \%$

$2.4 \quad(0.6,9.4) \quad 13 \%$

$5.8 \quad(1.2,28.2) \quad 10 \%$

$2.9 \quad(1.1,7.8) \quad 25 \%$

$3.1 \quad(1.9,5.0)$
Although BSS can have significant efficacy in the eradication of $\mathrm{H}$ pylori, by itself, it is not expected that the amounts ingested would be sufficient to sterilize the GI tract in a 48-h dosing regimen. Gorbach et al. [18] showed that among patients being prepared for colonoscopy the various populations of normal microbes from fecal samples were relatively unchanged in culture by a 1- or 2-day course of BSS. Therefore, BSS may be more effective against invading microbes than those colonizing the GI tract.

These recent data with new generation of diagnostics make the case for BSS as a potential first-line therapy for TD. Moreover, recent non-bacterial infectious epidemics such as recently well-publicized cruise-ship epidemics with Norovirus make TD situations particularly likely to have single organism etiologies. The susceptibility of these viral infectious agents to BSS is well documented [13]. Exceptions to BSS therapy should include more severely ill, febrile individuals with evidence of systemic signs such as dehydration, marked tachycardia, or inability to maintain oral intake to balance fluid losses by sweat and diarrhea.

BSS has a long history of safety when used as over-thecounter or prescribed medication $[46,47]$. A previous review (internal $\mathrm{P} \& \mathrm{G}$ data) of publically available post-marketing AE reports from consumers utilizing over-the-counter BSS (Pepto-Bismol ${ }^{\circledR}, \mathrm{P} \& \mathrm{G}$ Cincinnati, Ohio) over a period of more than 17 years found that the post-market AE profile of BSS was similar to the AE profile of clinical trials observed in this study. Furthermore, in patients with Helicobacter pylori-positive gastritis, BSS is commonly administered for $\mathrm{H}$ pylori eradication usually for 2 weeks due to its efficacy and benign AE profile [48]. Therefore, these clinical studies support that BSS, when administered in accordance with current OTC labeling, is safe, well tolerated. Although cases of overdosing with bismuth subsalicylate can lead to toxicities [46, 49, 50], such as tinnitus and even life threatening salicylism and bismuth neurotoxicity, their occurrence is rare. 
Table 3 Most common ( $\geq 2 \%$ in either treatment group) adverse events by MedDRA system organ class and preferred term (24 integrated BSS clinical studies in adults)

\begin{tabular}{lllr}
\hline $\begin{array}{l}\text { System organ class } \\
\text { Preferred term }\end{array}$ & $\begin{array}{l}\text { BSS }(N=1164) \\
n(\%)\end{array}$ & $\begin{array}{l}\text { Placebo }(N=1166) \\
n(\%)\end{array}$ & $p$ value \\
\hline $\begin{array}{l}\text { Gastrointestinal disorders } \\
\text { Feces discolored }\end{array}$ & $169(14.5 \%)$ & $25(2.1 \%)$ & $<0.0001$ \\
$\begin{array}{l}\text { Constipation } \\
\text { Tongue discolora- }\end{array}$ & $96(8.2 \%)$ & $16(1.4 \%)$ & $<0.0001$ \\
$\quad$ tion & $48(4.1 \%)$ & $36(3.1 \%)$ & 0.1844 \\
$\begin{array}{l}\text { Nausea } \\
\text { Diarrhea }\end{array}$ & $27(2.3 \%)$ & $41(3.5 \%)$ & 0.1090 \\
$\begin{array}{l}\text { Nervous system disorders } \\
\text { Headache }\end{array}$ & $37(3.2 \%)$ & $47(4.0 \%)$ & 0.3172 \\
$\begin{array}{l}\text { Metabolism and } \\
\text { nutrition disor- } \\
\text { ders }\end{array}$ & & \\
$\begin{array}{l}\text { Decreased appe- } \\
\text { tite }\end{array}$ & $43(3.7 \%)$ & $35(3.0 \%)$ & 0.3597 \\
\hline
\end{tabular}

$N=$ number of subjects within specified treatment. $n(\%)=$ number and percent of subjects who reported adverse events within specified treatment. $p$ value: Fisher's exact test

A clinical study demonstrated that orally administered bismuth salts were in general poorly absorbed and that BSS in particular had significantly lower potential for systemic bismuth exposures than other bismuth salts such as colloidal bismuth subcitrate or bismuth subgallate [51].

From the integrated safety analysis, the most common AEs experienced by subjects receiving BSS were discoloration of the feces or tongue; this is a benign and well-established condition associated with the use of bismuth salts due to formation of bismuth sulfide (a black color salt) from bismuth reaction with hydrogen sulfide present in the feces or food residues. Other non-serious gastrointestinal events such as constipation, diarrhea, nausea, and vomiting were conditions for which the population was being treated and were present in both placebo and BSS treatment groups similarly.

The limitations of our analyses comprise elements of individual study design and population samples and endpoints. Although all studies followed similar definitions of diarrhea which was the primary endpoint analyzed, not all studies included assessment of other symptoms commonly associated with diarrhea, such as nausea, vomiting, abdominal discomfort, gases, and pain which would have enriched the clinical aspects of the benefits brought by BSS treatment or prevention of diarrhea. Pathogen analysis confirming infectious nature of diarrhea was not done in studies used to compare doses and different concentrations of the active BSS and therefore was not included in our analysis or discussion of efficacy. Nevertheless, it is well accepted that traveler's diarrhea is a subset of infectious gastroenteritis.
Overall, the current meta-analysis with BSS shows significant benefits in prevention and treatment of TD with the additional importance of recognizing non-antibiotic overthe-counter treatment as a potential first-line treatment for a highly prevalent condition that has been suspected of largely contributing to antibiotic resistance. We agree with the work of DuPont and others that the management and prevention of TD are not a simple matter [34]. Clearly, research into the role of all agents used in this global illness needs to be stimulated, particularly with review and consensus development as well as new research initiatives such as personalized medicine and antibiotic husbandry.

Acknowledgments The authors wish to thank April S. Woods, Maria Hooker, and Judith M. Pepin, PhD, for their valued assistance in the preparation of this manuscript. All authors are responsible for the content and have read and approved the final manuscript. All authors had full access to the data and their analysis, as well as drafting the article or editing an author's draft.

Authors' contribution All authors contributed to conceptualization, data analysis, interpretation, and manuscript preparation.

\section{Compliance with Ethical Standards}

Conflict of interest Jose M. Brum MD, Roger D. Gibb PhD, David L. Ramsey MS, and Guhan Balan PhD are currently full-time employees of the Procter \& Gamble Company. All remaining authors have declared no conflicts of interest.

Open Access This article is licensed under a Creative Commons Attribution-NonCommercial 4.0 International License, which permits any non-commercial use, sharing, adaptation, distribution and reproduction in any medium or format, as long as you give appropriate credit to the original author(s) and the source, provide a link to the Creative Commons licence, and indicate if changes were made. The images or other third party material in this article are included in the article's Creative Commons licence, unless indicated otherwise in a credit line to the material. If material is not included in the article's Creative Commons licence and your intended use is not permitted by statutory regulation or exceeds the permitted use, you will need to obtain permission directly from the copyright holder. To view a copy of this licence, visit http://creativecommons.org/licenses/by-nc/4.0/.

\section{References}

1. Farthing MJ. Diarrhea: a significant worldwide problem. Int $J$ Antimicrob Agents. 2000;14:65-69.

2. Scallan E, Griffin PM, Angulo FJ, et al. Foodborne illness acquired in the United States-unspecified agents. Emerg Infect Dis. 2011;17:16-22.

3. Patel MM, Hall AJ, Vinje J, Parashar UD. Noroviruses: a comprehensive review. J Clin Virol. 2009;44:1-8.

4. Yen C, Wikswo ME, Lopman BA, et al. Impact of an emergent norovirus variant in 2009 on norovirus outbreak activity in the United States. Clin Infect Dis. 2010;53:568-571.

5. CDC. National Center for Emerging and Zoonotic Infectious Diseases (NCEZID), Division of Foodborne, Waterborne, and 
Environmental Diseases (DFWED). Last updated July 15, 2016. https://www.cdc.gov/foodborneburden/2011-foodborne-estimates. html.

6. GBD 2015 Mortality and Causes of Death Collaborators. Global, regional, and national life expectancy, all-cause mortality, and cause-specific mortality for 249 causes of death, 1980-2015: a systematic analysis for the Global Burden of Disease Study 2015. Lancet 2016; 388: 1459-1544.

7. Hall AJ, Lopman BA, Payne DC, et al. Norovirus disease in the United States. Emerg Infect Dis. 2013;19:1198-1205.

8. CDC. Vessel Sanitation Program. Centers for Disease Control and Prevention: Norovirus. http://www.cdc.gov/nceh/vsp/default.htm.

9. Connor BA. CDC Health Information for International Travel 2016: the yellow book. In: Brunette GW, ed. Chapter 2, The pre-travel consultation, self-treatable conditions: travelers' diarrhea. New York, NY: Oxford University Press; 2016.

10. Manhart MD. In vitro antimicrobial activity of bismuth subsalicylate and other bismuth salts. Rev Infect Dis. 1990;12:S11-S15.

11. Menge H, Gregor M, Brosius B, et al. Pharmacology of bismuth. Eur J Gastroenterol Hepatol. 1992;4:S41-S47.

12. Raedsch R, Walter-Sack I, Weber E, Blessing J. Pharmacokinetics of bismuth preparations in patients with gastritis and ulcer disease. Klin Wochenschr. 1990;68:488.

13. Pitz AM, Park GW, Lee D, et al. Antimicrobial activity of bismuth subsalicylate on Clostridium difficile, Escherichia coli O157:H7, norovirus, and other common enteric pathogens. Gut Microbes. 2015;6:93-100.

14. Gump DW, Nadeau OW, Hendricks GM, Meyer DH. Evidence that bismuth salts reduce invasion of epithelial cells by enteroinvasive bacteria. Med Microbiol Immunol. 1992;181:131-143.

15. Nadeau OW, Gump DW, Hendricks GM, Meyer DH. Deposition of bismuth by Yersinia enterocolitica. Med Microbiol Immunol. 1992;181:145-152.

16. Sox TE, Olson CA. Binding and killing of bacteria by bismuth subsalicylate. Antimicrob Agents Chemother. 1989;33:2075-2082.

17. Cornick NA, Silva M, Gorbach SL. In vitro antibacterial activity of bismuth subsalicylate. Rev Infect Dis. 1990;12:S9-S10.

18. Gorbach SL, Cornick NA, Silva M. Effect of bismuth subsalicylate on fecal microflora. Rev Infect Dis. 1990;12:S21-S23.

19. DuPont HL. Guidelines on acute infectious diarrhea in adults. The Practice Parameters Committee of the American College of Gastroenterology. Am J Gastroenterol. 1997;92:1962-1975.

20. DuPont HL. Bismuth subsalicylate in the treatment and prevention of diarrheal disease. Drug Intell Clin Pharm. 1987;21:687-693.

21. DuPont HL, Sullivan P, Evans DG, et al. Prevention of traveler's diarrhea (emporiatric enteritis). Prophylactic administration of subsalicylate bismuth. JAMA. 1980;243:237-241.

22. Gryboski JD, Hillemeier AC, Grill B, Kocoshis S. Bismuth subsalicylate in the treatment of chronic diarrhea of childhood. Am J Gastroenterol. 1985;80:871-876.

23. Steinhoff MC, Douglas RG Jr, Greenberg HB, Callahan DR. Bismuth subsalicylate therapy of viral gastroenteritis. Gastroenterology. 1980;78:1495-1499.

24. Steffen R, Dupont HL, Heusser R, et al. Prevention of traveler's diarrhea by the tablet form of bismuth subsalicylate. Antimicrob Agents Chemother. 1986;29:625-627.

25. Dupont HL, Ericsson CD, Johnson PC, et al. Preventing traveler's diarrhea by the tablet formulation of bismuth subsalicylate. JAMA. 1987;257:1347-1350.

26. Sun H, Zhang L, Szeto KY. Bismuth in medicine. Met Ions Biol Syst. 2004;41:333-378.

27. Salvador JA, Figueiredo SA, Pinto RM, Silvestre SM. Bismuth compounds in medicinal chemistry. Future Med Chem. 2012;4:1495-1523.
28. Johnson PC, Ericsson CD, Dupont HL, et al. Comparison of loperamide with bismuth subsalicylate for the treatment of acute travelers' diarrhea. JAMA. 1986;255:757-760.

29. DuPont HL, Sullivan P, Pickering LK, et al. Symptomatic treatment of diarrhea with bismuth subsalicylate among students attending a Mexican university. Gastroenterology. 1977;73:715-718.

30. Sun H, Zhang L, Szeto KY. Bismuth in medicine. In: Metal ions in biological systems, metal ions and their complexes in medication. Marcel Dekker; New York. 2004; Volume 41, pp. 333-378.

31. McGlone SM, Bailey RR, Zimmer SM, et al. The economic burden of Clostridium difficile. Clin Microbiol Infect. 2012;18:282-289.

32. Doi Y, Iovleva A, Bonomo RA. The ecology of extended-spectrum $\beta$-lactamases (ESBLs) in the developed world. J Travel Med. 2017;24:S44-S51.

33. Woerther P, Andremont A, Kantele A. Travel-acquired ESBL-producing Enterbacteriaceae: impact of colonization at individual and community level. J Travel Med. 2017;24:S29-S34.

34. DuPont HL, Steffen R. Use of antimicrobial agents for treatment and prevention of travellers' diarrhea in the face of enhanced risk of transient fecal carriage of multi-drug resistant enterobacteriaceae: setting the stage for consensus recommendations. J Travel Med. 2017;24:S57-S62.

35. Owens RC, Donskey CJ, Gaynes RP, et al. Antimicrobial risk factors for Clostridium difficile infection. Clin Infect Dis. 2008;46:S19-S31.

36. Ericsson CD, Evans DG, DuPont HL, et al. Bismuth subsalicylate inhibits crude toxins of Escherichia coli and Vibrio cholera.J Infect Dis. 1997;136:693-696.

37. Ericsson CD, Tannenbaum C, Charles TT. Antisecretory and antiinflammatory properties of bismuth subsalicylate. Rev Infect Dis. 1990;12:S16-S20.

38. Graham DY, Estes MK, Gentry LO. Double-blind comparison of bismuth subsalicylate and placebo in the prevention and treatment of enterotoxigenic Escherichia coli-induced diarrhea in volunteers. Gastroenterology. 1983;85:1017-1022.

39. Soriano-Brucher H, Avendano P, O'Ryan M, et al. Bismuth subsalicylate in the treatment of acute diarrhea in children: a clinical study. Pediatrics. 1991;87:18-27.

40. Steffen R, Mathewson JJ, Ericsson CD, Dupont HL. Travelers' diarrhea in West Africa and Mexico: fecal transport systems and liquid bismuth subsalicylate for self-therapy. J Infect Dis. 1988;157:1008-1013.

41. León-Barúa R, Tello R, Morante MC, et al. In vitro and in vivo effects of three bismuth compounds on fermentation by colonic bacteria. Rev Infect Dis. 1990;12:S24-S29.

42. Antikainen J, Kantele A, Pakkanen SH, et al. A quantitative polymerase chain reaction assay for rapid detection of 9 pathogens directly from stools of travelers with diarrhea. Clin Gastroenterol Hepatol. 2013;11:1300-1307. e3.

43. Koziel M, Kiely R, Blake L, et al. Improved detection of bacterial pathogens in patients presenting with gastroenteritis by use of the EntericBio real-time Gastro Panel I assay. J Clin Microbiol. 2013;51:2679-2685.

44. Liu J, Gratz J, Maro A, et al. Simultaneous detection of six diarrheacausing bacterial pathogens with an in-house PCR-luminex assay. $J$ Clin Microbiol. 2012;50:98-103.

45. Bowen A, Agboatwallam, Pitz AM, et al. Bismuth subsalicylate reduces antimicrobial use among adult diarrhea patients in Pakistan: a randomized placebo controlled, triple masked clinical trial. Abstract (\#1202) presented at the American Society of Tropical Medicine and Hygiene. 65th Annual Meeting 2016 Atlanta, GA, USA.

46. Bierer DW. Bismuth subsalicylate: history, chemistry, and safety. Rev Infect Dis. 1990;12:S3-S8.

47. Proudfoot AT. Toxicity of Salicylates. Am J Med. 1983;14:99-103.

48. Noach LA, Eekhof JL, Bour LJ, et al. Bismuth salts and neurotoxicity. A randomised, single-blind and controlled study. Hum Exp Toxicol. 1995;14:349-355. 
49. Thomas RJ. Neurotoxicity of antibacterial therapy. South Med J. 1994;87:869-874.

50. Pearlman BL, Gambhir R. Salicylate intoxication: a clinical review. Postgrad Med. 2009;121:162-168.

51. Dresow B, Fischer R, Gabbe EE, et al. Bismuth absorption from bi-205-labeled pharmaceutical bismuth compounds used in the treatment of peptic-ulcer disease. Scand J Gastroenterol. 1992;27:333-336.
Publisher's Note Springer Nature remains neutral with regard to jurisdictional claims in published maps and institutional affiliations. 